\author{
Scientific Electronic Archives \\ Issue ID: Sci. Elec. Arch. Vol. 14 (10) \\ October 2021 \\ DOI: http://dx.doi.org/10.36560/141020211435 \\ Article link: https://sea.ufr.edu.br/SEA/article/view/1435
}

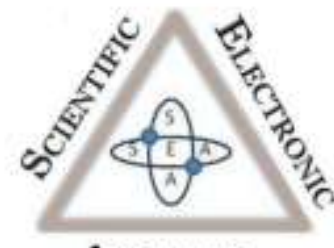

ARCHIVES

ISSN 2316-9281

\title{
Effect of thermal modification on wood properties of 38-year-old Cariniana legalis cultivated at different spacing
}

\author{
Juraci de Andrade Barbosa \\ Instituto de Pesquisas Ambientais \\ Bruno Miranda da Silva \\ Instituto de Pesquisas Ambientais \\ Maurício Ranzini \\ Instituto de Pesquisas Ambientais \\ Eduardo Luiz Longui \\ Instituto de Pesquisas Ambientais \\ Corresponding author \\ Israel Luiz de Lima \\ Instituto de Pesquisas Ambientais \\ limailde@gmail.com
}

\begin{abstract}
Planting spacing influences wood production. However, for tropical species we have scarce information about the effect of spacing on production and wood quality. In general, wood from native species produced in reforestation does not have the same quality compared to that from natural forests. Then, wood thermal modification can help improve the potential for using wood. In this context, our goal was to evaluate the influence of thermal modification on properties of 38-year-old Cariniana legalis wood cultivated at different spacing ( $3 \times 1.5 \mathrm{~m}, 3 \times 2 \mathrm{~m}$ and $3 \times 2.5 \mathrm{~m})$ at the Luiz Antônio Experimental Station, Luiz Antônio City, São Paulo. We felled 15 trees, five of each spacing, and from each tree, a log, 1 meter in length, a central plank was cut, and from these planks, we cut specimens for anatomical and wood properties investigations according to standard techniques. In the specimens, a thermal modification at a temperature of $200^{\circ} \mathrm{C}$ was carried out for one hour and after the specimens were compared with the control specimens. According to the results presented, we found that spacing did not influence vessel diameter, apparent density and volumetric shrinkage significantly. Thermal modification reduced apparent density and volumetric shrinkage. The reduction in vessel diameter can be estimated as a function of the wood thermal modification.
\end{abstract}

Keywords: physical properties, tropical species, wood anatomical dimensions, wood quality.

\section{Introduction}

Wood thermal modification is a process that uses high levels of heat and temperature, aiming to reduce the presence of water in the wood so that it has greater dimensional stability and hinders deterioration by wood-reducing agents and environmental damage. However, each species subjected to heat treatment has differences, which are based on their chemical, physical and anatomical features, the thermal modification process is applied to several woody species with different purposes (Modes et al., 2017). We emphasize that wood that undergoes the thermal modification process may have improvements in some properties and aesthetics, but may present mass loss, which affects its density and, consequently, its mechanical properties (Garcia et al., 2012).

In Brazil, most of research with thermally modified wood was carried out in exotic woods used in reforestation, mainly Eucalyptus spp. and Pinus spp. There is, therefore, a knowledge gap to understand the results of thermal modification in tropical species, which may expand technological potential of these woods and their commercial exploitation (Lobato et al., 2020). 
Our group has been investigating several woods native to Brazil, in particular, Cariniana legalis (Mart.) Kuntze (jequitibá rosa), with very promising results for the use of wood (Lima et al., 2011a; Oliveira et al., 2018). Cariniana legalis is a native species found in the Atlantic Forest, including the north-eastern (Bahia, Paraíba and Pernambuco), south-eastern (Espírito Santo, Minas Gerais, Rio de Janeiro and São Paulo) and southern (Paraná) parts of Brazil (Smith et al., 2015). It is one of the biggest tree species of the Brazilian flora, reaching 30-50 m in height and $70-100 \mathrm{~cm}$ in diameter and can potentially produce up to $21 \mathrm{~m}^{3}$. ha $\mathrm{h}^{-1}$. year ${ }^{-1}$ stem wood (Carvalho, 2003). It is, therefore, one of the most promising native tree species for use in forest plantations, in monocultures or mixed with other species, and for restoration of degraded areas (Carvalho, 1994).

Cariniana legalis trees can be planted in full sun, with naturally straight stems, but the growth and straight stem shape are favored in intercropping, reducing the need for pruning and favoring height growth (Rolim et al., 2018). The species can be planted in pure, mixed and agroforestry systems, where it has been shown to be a very adaptable species to these different planting models (Ciriello et al., 2021). Homogeneous planting of 38-year-old Cariniana legalis can produce up to $17 \mathrm{~m}^{3}$. ha ${ }^{-1}$. year ${ }^{-1}$ of wood with an apparent density of $799 \mathrm{~kg} \cdot \mathrm{m}$ ${ }^{3}$ (Oliveira et al., 2018).

In forest planting planning, one of the most important things to define is the adequate spacing, so that there is greater production and better wood quality. Most studies on spacing are focused on growth characteristics, and little is known about its influence on wood properties, especially regarding native species, and much less about the relationship with the wood thermal modification process.

In this context, our goal was to evaluate the influence of thermal modification on properties of 38year-old Cariniana legalis wood cultivated at different spacing $(3 \times 1.5 \mathrm{~m}, 3 \times 2 \mathrm{~m}$ and $3 \times 2.5 \mathrm{~m})$ Thus, we hypothesize that spacing between trees has an influence on wood anatomy and properties.

\section{Materials and Methods \\ Study area and sampling}

Wood samples for this study were collected from 38-year-old Cariniana legalis trees from an experimental plantation at the Luiz Antônio Experimental Station (LAES), Luiz Antônio City, São Paulo State $\left(21^{\circ} 40^{\prime} \mathrm{S}, 47^{\circ} 49^{\prime} \mathrm{W}\right.$, elevation $\left.550 \mathrm{~m}\right)$ (Gurgel-Garrido et al., 1997). The relief has an inclination around $5 \%$, and the soil is Red Latosol type medium texture (LV) (Santos et al., 2018). It has a Köppen Aw climate classification, with an average annual temperature of $20.7^{\circ} \mathrm{C}$, and an average annual precipitation of $1,463 \mathrm{~mm}$ (Flores et al., 2016). According to CEPAGRI (2020), the warmest months occurring in January, February and March and the coldest months occurring in May, June and July.
The planting was established at three different spacings $(3 \times 1.5 \mathrm{~m}, 3 \times 2 \mathrm{~m}$ and $3 \times 2.5 \mathrm{~m})$, with one external border row of the same species, without fertilization. For wood collection we identified 15 trees, five of each spacing (Table 1).

Table 1. Dendrometric data of 38-year-old Cariniana legalis trees at three different spacings. $\mathrm{HT}=$ height, $\mathrm{DBH}$ $=$ diameter at breast height.

\begin{tabular}{lcc}
\hline Spacing & $\mathrm{HT}(\mathrm{m})$ & $\mathrm{DBH}(\mathrm{cm})$ \\
\hline $3 \times 1.5 \mathrm{~m}$ & 20.78 & 17.84 \\
$3 \times 2.0 \mathrm{~m}$ & 21.46 & 18.52 \\
$3 \times 2.5 \mathrm{~m}$ & 21.50 & 21.94 \\
\hline
\end{tabular}

\section{Thermal modification}

From 15 trees collected, and from each tree, a log, 1 meter in length, was cut at the region immediately below the breast height. From logs, a central plank (7 cm thick) was cut, and from these planks, we cut battens $(4 \times 4 \times 100 \mathrm{~cm})$ and from battens, specimens of $2 \times 2 \times 3 \mathrm{~cm}$ were obtained. In total, 30 specimens were obtained, 10 of each spacing. Of this total, 15 were separated to be a control, i.e., without thermal modification treatment, 5 of each spacing and the other 15 were submitted to thermal modification treatment, 5 of each spacing. Therefore, 15 specimens were placed in an oven, at a temperature of $200^{\circ} \mathrm{C}$, for a period of one hour. After this procedure, these specimens were removed from the oven and placed in a desiccator. Then, assessments of these specimens were started.

\section{Physical and anatomical properties}

The following wood properties were evaluated: apparent density (AD), vessel diameter (VD) and volumetric shrinkage (VS). The AD and VS was determined according to NBR 7190 (ABNT, 1997). In the samples that underwent the thermal modification process, vessel diameters were evaluated, measuring 25 diameters of each sample, totaling 125 per treatment, the terminology and characterization of wood followed the IAWA (IAWA Committee, 1989), and Paneque et. al. (2019).

\section{Statistical analyses}

A completely randomized experimental design was used to analyze the properties, in a $3 \times 2$ factorial scheme [three spacing $x$ two treatments (with and without thermal modification)]. Tukey's test was applied whenever a significant difference was observed, at the $5 \%$ probability level, of any treatment in the $\mathrm{F}$ test. Data analysis was performed according using SAS $\AA$ software for Windows (SAS Institute, Inc., 1999).

\section{Results and discussion}

Planting spacing did not significantly affect: apparent density, volumetric shrinkage and vessel diameter in $C$. legalis. Thermal modification significantly influenced apparent density and volumetric shrinkage, however, vessel diameter was not influenced (Table 2). There was no significant 
interaction between planting spacing and wood thermal modification for all properties under study, which demonstrates that there is no dependence between these two factors (Table 2).

Table 2. Analysis of variance for apparent density, vessel diameter, and volumetric shrinkage, in function of three different spacing and thermal modification treatment.

\begin{tabular}{lcccc}
\hline \multirow{2}{*}{ Sources of variation } & DF & \multicolumn{3}{c}{ Mean squares } \\
\cline { 2 - 5 } & & $\mathrm{AD}$ & $\mathrm{VD}$ & $\begin{array}{c}\text { VS } \\
(\%)\end{array}$ \\
\hline $\mathrm{S}$ & 2 & $308.0930^{\text {n.s. }}$ & $574.3405^{\text {n.s. }}$ & $7.3037^{\text {n.s. }}$ \\
$\mathrm{T}$ & 1 & $21412.2328^{\text {*x }}$ & $472.8843^{\text {n.s. }}$ & $40.5761^{\text {*x }}$ \\
$\mathrm{S} \times \mathrm{T}$ & 2 & $981.4747^{\text {n.s. }}$ & $57.3193^{\text {n.s. }}$ & $1.2863^{\text {n.s. }}$ \\
Residual & 24 & 1606.8895 & 372.0812 & 3.2651 \\
\hline Mean & & 640.07 & 68.75 & 11.02 \\
$\mathrm{SD}$ & & 46.44 & 19,17 & 2,16 \\
$\mathrm{CV}$ (\%) & 6.26 & 28.05 & 16.39 \\
\hline
\end{tabular}

apparent density = AD; vessel diameter $=\mathrm{VD}$; volumetric shrinkage $=\mathrm{VS}$; degrees of freedom $=\mathrm{DF}$; spacing $=\mathrm{S}$; treatment $=\mathrm{T}$ Standard deviation $=$ SD. n.s. $=$ not significant, ${ }^{*}=$ significant at $5 \%$ probability of error, ${ }^{* *}=$ significant at $1 \%$ probability of error, and $\mathrm{CVe}=$ coefficient of experimental variation.

The mean values of $A D, V D$, and $V S$ and was $640 \mathrm{~kg} \cdot \mathrm{m}^{-3}, 68 \square \mathrm{m}$, and $11 \%$, respectively (Table 2). Apparent density and volumetric shrinkage values are close to those reported by Rolim et al. (2018). Narrower vessels were observed when compared with Lima et al. (2011a), who reported vessel diameter between 84 to 131 $\mu \mathrm{m}$, from the pith to the bark, respectively, of 26year-old Cariniana legalis wood. This difference in the results when compared to literature demonstrates that there is variation in wood properties of Cariniana legalis, and this is a function, e.g., local planting conditions, tree age and genetic material.

We observed that planting spacing did not significantly influence Cariniana legalis wood properties (Tables 2 and 3). One of the possible explanations for these results would be the fact that the three different spacings tested do not result in enough vital spaces to significantly alter wood properties. This same trend was verified by Eloy et al. (2015), who also did not observe a significant difference in the basic density in Mimosa scabrella wood as a function of planting spacing. However, different spacing influenced the variation in basic density in Mimosa scabrella and Ateleia glazioveana wood, but there was no systematic positive or negative variation in relation to spacing (Eloy et al. 2013). In a study with Tectona grandis, Lima et al. (2009), they also found that volumetric shrinkage was not influenced by planting spacing. Vessel diameter in $T$. grandis also did not vary significantly as a function of different spacing (Lima et al. 2011b). We found that the three different spacings tested were not enough to significantly alter the wood properties of Cariniana legalis. The thermal modification of the wood significantly reduced the apparent density and volumetric shrinkage of Cariniana legalis, vessel diameter was reduced, but not significantly (Table 3).

Table 3. Average values for apparent density, vessel diameter, and volumetric shrinkage, in function of the three different spacings and thermal modification treatment.

\begin{tabular}{lccc}
\hline Spacing & AD $\left(\mathrm{kg} \cdot \mathrm{m}^{-3}\right)$ & VD $(\mu \mathrm{m})$ & VS $(\%)$ \\
\hline $3 \times 1.5 \mathrm{~m}$ & $633.95^{\mathrm{a}}(51.96)$ & $75.64^{\mathrm{a}}(18.27)$ & $10.85^{\mathrm{a}}(2.47)$ \\
$3 \times 2.0 \mathrm{~m}$ & $644.77^{\mathrm{a}}(184.48)$ & $69.98^{\mathrm{a}}(16.39)$ & $11.95^{\mathrm{a}}(3.21)$ \\
$3 \times 2.5 \mathrm{~m}$ & $641.52^{\mathrm{a}}(37.98)$ & $60.64^{\mathrm{a}}(21.32)$ & $10.26^{\mathrm{a}}(2.23)$ \\
\hline Unmodified wood & $666.80^{\mathrm{a}}(41.92)$ & $72.72^{\mathrm{a}}(21.15)$ & $12.18^{\mathrm{a}}(1.80)$ \\
Modified wood & $613.36^{\mathrm{b}}(34.37)$ & $64.78^{\mathrm{a}}(16.74)$ & $9.85^{\mathrm{b}}(1.89)$ \\
\hline
\end{tabular}

means with the same letter do not differ statistically according to Tukey's test, standard deviation in parentheses.

Brito et al. (2006) verified that the thermal modification had little influence on the wood density of Eucalyptus grandis, and the variation occurred as a function of the rise in temperature. This same trend was observed by Cademartori et al. (2015) in Eucalyptus sp. wood. Calonego et al. (2014) observed that the thermal treatment of Eucalyptus sp. wood reduced the apparent density by $6.8 \%$.

Volumetric shrinkage was significantly reduced due to thermal modification (Table 3 ). Lobato et al. (2020) studying Jacaranda copaia wood reported significant difference between volumetric shrinkage of thermally modified and unmodified wood, with lower values occurring for treatment at $240{ }^{\circ} \mathrm{C}$ for $2 \mathrm{~h}$, and higher values for samples at $240{ }^{\circ} \mathrm{C}$ for $1 \mathrm{~h}$. Lower values of volumetric shrinkage are very important when considering the use of wood that requires little dimensional instability, e.g., floor, doors, windows and furniture.

The marked effect of thermal treatment on the dimensional stability of wood is justified by the reduction in hygroscopicity, due to the degradation of hemicellulose, which reduces the wood's ability to 
exchange water with the outside environment, and thus minimizes the effects of dimensional wood variation (Quirino and Vale, 2002; Menezes et al. 2014). Cademartori et al. (2015) also found a decrease in dimensional stability due to thermal modification in Eucalyptus grandis and Eucalyptus saligna woods. Lopes et. al. (2014), in a study with Tectona grandis wood, after thermal modification, in the heartwood and sapwood, they observed a decrease in the equilibrium moisture content, and the increase in temperature caused by this more pronounced effect.

We observed a small reduction in vessel diameter due to thermal modification, but this variation was not significant (Table 3 ). This same trend was verified in Eucalyptus grandis wood by Paneque et al. (2019). However, a significant reduction in vessel diameter when comparing Enterolobium schomburgkii wood and charcoal was found by Muñiz et al. (2012).

Figure 1 shows a more detailed analysis of thermal modification effect in wood as a function of each spacing, separately. In apparent density, it is verified that wood from the $3 \times 2.5 \mathrm{~m}$ spacing was more stable, being less influenced by thermal modification, and wood from the $3 \times 2 \mathrm{~m}$ spacing was the most influenced, having a reduction of $10.64 \%$ in apparent density (Figure 1A). For volumetric shrinkage, the wood from the $3 \times 1.5 \mathrm{~m}$ spacing was the most influenced by thermal treatment with a reduction of $25.36 \%$ in wood shrinkage, wood from $3 \times 2 \mathrm{~m}$, and $3 \times 2.5$ spacing was less influenced, and presents practically the same behaviors (Figure 1C).

As seen above, vessel diameter was not significantly influenced by thermal modification of wood, but when analyzed separately, it appears that in the $3 \times 2 \mathrm{~m}$ spacing there was a reduction of $14.64 \%$ in vessel diameter, and in the spacing of $3 x$ $2.5 \mathrm{~m}$ a reduction of only $3.92 \%$ (Figure $1 \mathrm{~B}$ ). To better illustrate this relationship of vessel diameter with and without thermal modification, a regression study was performed (Figure 2).

We observed a significant relationship between vessel diameter without thermal modification and vessel diameter with thermally modified wood (Figure 2). According to the regression model, there is a trend of proportional increase between vessel diameter without thermal modification and vessel diameter of thermally modified wood (Figure 2). Therefore, it is possible to estimate what the reduction of the vessel diameter will be, as a function of thermal modification of the wood.

Although the quality of Cariniana legalis wood from natural forests is already well known, little is known about the wood behavior when produced in planted forests and also about the use of available technologies to improve its use and quality. Therefore, further studies on these topics are needed to improve the use of Cariniana legalis wood, which has great potential to be produced on a large scale and used by the timber industry.
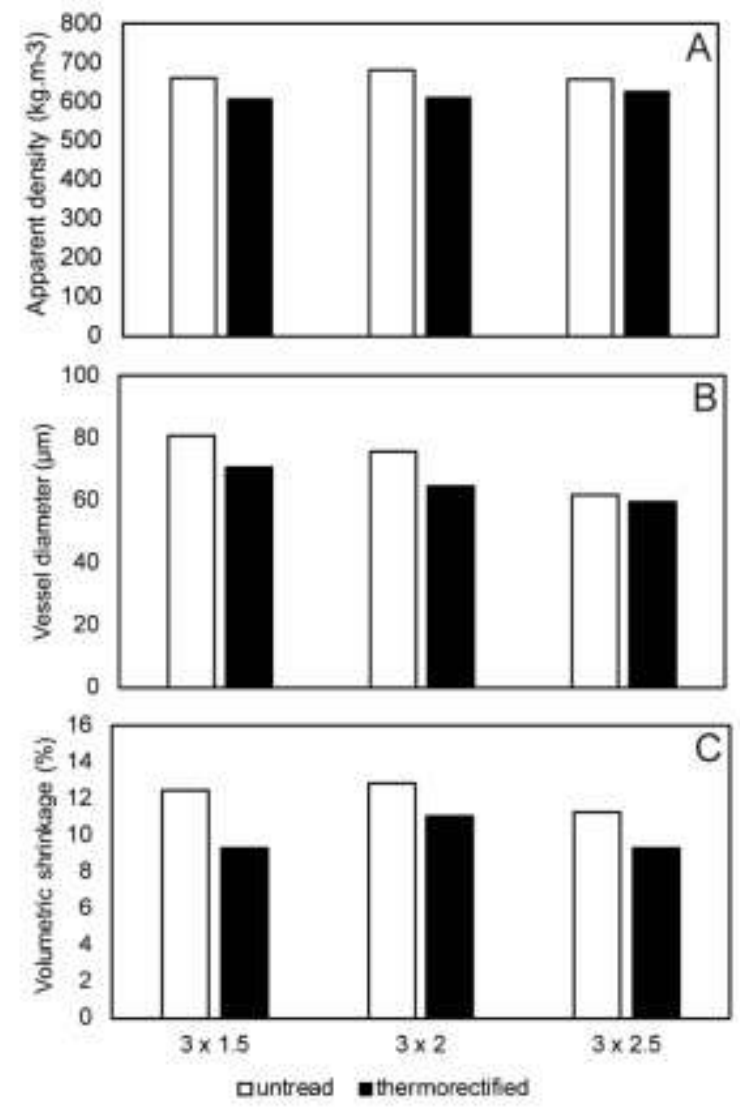

Figure 1. Apparent density, vessel diameter and volumetric shrinkage as in function of three different spacing and thermal modification treatment in 38-year-old Cariniana legalis wood. 


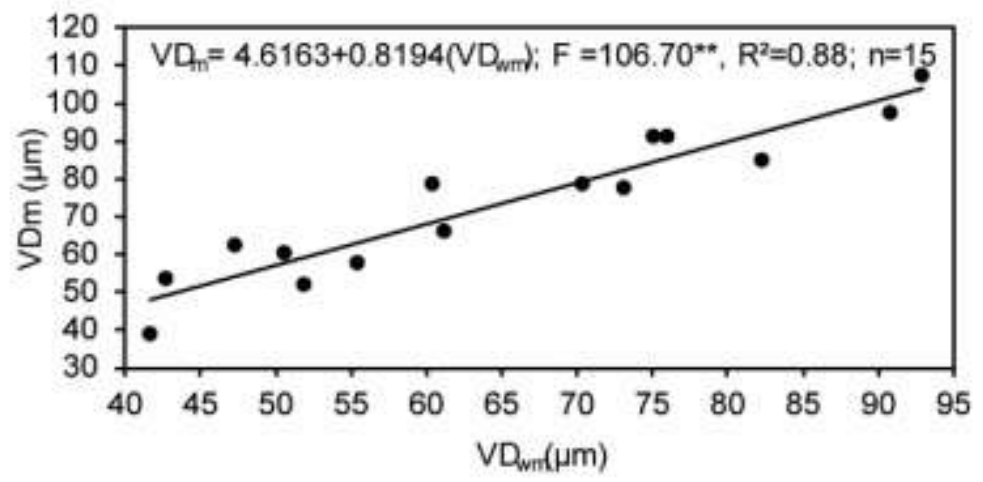

Figure 2. Relation between vessel diameter without thermal modification (VDwm) and vessel diameter with thermal modification (VDm) in 38-year-old Cariniana legalis wood.

\section{Conclusion}

We conclude that planting spacing did not influence apparent density, volumetric shrinkage and vessel diameter. Thermal modification affected apparent density and volumetric shrinkage. Vessel diameter was not influenced by wood thermal modification. Apparent density of thermally modified wood is lower than that of untreated wood. The volumetric shrinkage of thermally modified wood is less than that of untreated wood. The vessel diameter of non-thermally modified wood has a good relationship with the vessel diameter of thermally modified wood. We can estimate the vessel diameter reduction as a function of the wood thermal modification

\section{Acknowledgment}

The authors thank Sonia Regina Godoi Campião for laboratory assistance (Forestry Institute - IF). We are grateful to the FUNDAP (Fundação do Desenvolvimento Administrativo) for a grant to Bruno Miranda da Silva.

\section{References}

ASSOCIAÇÃO BRASILEIRA DE NORMAS TÉCNICAS - ABNT. Normas Técnicas. NBR 7190: Projeto de Estruturas de Madeira. Rio de Janeiro, 1997, 107p.

BRITO, J.O., GARCIA, J.N., BORTOLETTO, G., PESSOA, A.M.C., SILVA, P.H.M. Densidade básica e retratibilidade da madeira de Eucalyptus grandis submetida a diferentes temperaturas de termorretificação. Cerne, Vol. 12, n. 2, p. 181-188, 2006.

CADEMARTORI, P.H.G.D., MISSIO, A.L., MATTOS, B.D., GATTO, D.A. Effect of thermal treatments on technological properties of wood from two Eucalyptus species. Anais da Academia Brasileira de Ciências, Vol. 87, n. 1, p. 471-481, 2015.
CALONEGO, F.W., SEVERO, E.T.D., LATORRACA, J.V.F. Effect of thermal modification on the physical properties of juvenile and mature woods of Eucalyptus grandis. Floresta e Ambiente, Vol. 21, n. 1, p. 108-113, 2014.

CARVALHO, P.E.R. Espécies florestais brasileiras: recomendações silviculturais, potencialidades de uso da madeira. Colombo: Embrapa, 1994.

CARVALHO, P.E.R. Espécies arbóreas brasileiras. Brasília: Embrapa Informação Tecnológica; Colombo: Embrapa Florestas, 2003.

CENTRO DE PESQUISAS METEOROLÓGICAS E CLIMÁTICAS APLICADAS À AGRICULTURA CEPAGRI. Clima dos Municípios Paulistas. http://www.cpa.unicamp.br/outrasinformacoes/clima-dosmunicipiospaulistas. Accessed 11/12/2020.

CIRIELLO, E., PINA-RODRIGUES, F.C.M., SATO, L.M., MORAES, M.A., CIRIELLO, V., FREITAS, M.L.M. Cariniana legalis (Mart.) Kuntze). In: PIÑARODRIGUES, F.C.M., SILVA, J.M.S. (Org.). Silvicultura tropical: o potencial madeireiro e não madeireiro das espécies tropicais. 1ed.Sorocaba: Ed. dos Autores, 2021, p. 146-163.

ELOY, E., CARON, B.O., TREVISAN, R., SCHMIDT, D., ZANON, M.L.B., BEHLING, A., MONTEIRO, G.C. Variação longitudinal e efeito do espaçamento na massa específica básica da madeira de Mimosa scabrella e Ateleia glazioveana. Floresta, Vol. 43, n. 2, p. 327-334, 2013.

ELOY, E., SILVA, D.A., CARON, B.O., SOUZA, V.Q., BEHLING, A., ELLI, E.F., MONTEIRO, G.C. Caracterização da biomassa da madeira e da casca de Mimosa scrabrella Benth cultivada em dois diferentes espaçamentos. Ciência da Madeira, Vol. 6, n. 1, p. 38-46, 2015. 
FLORES, T.B., ALVARES, C.A., SOUZA, V.C., STAPE, J.L. Eucalyptus no Brasil: Zoneamento climático e guia para identificação. Piracicaba: IPEF, 2016. 448 p.

GARCIA, R.A., CARVALHO, A.M., LATORRACA, J.V.F., MATOS, J.L.M., SANTOS, W.A., SILVA, R.F.M. Nondestructive evaluation of heat-treated Eucalyptus grandis Hill ex Maiden wood using stress wave method. Wood Science and Technology, Vol. 46, n. 1-3, p. 41-52, 2012.

GURGEL-GARRIDO, L.M.A., SIQUEIRA A.C.M.F., CRUZ, S.F., ROMANELLI, R.C., ETTORI, L.G., CRESTANA, C.S.M., SILVA, A.A., MORAIS, E., ZANATTO, A.C.S., SATO, A.S. Programa de melhoramento genético florestal do Instituto Florestal. IF Série Registros, n. 18, p. 1-53. 1997.

IAWA COMMITEE. List microscope features of hardwood identification. IAWA Bulletin, Leiden, Vol. 10, n. 3, p. 221-259, 1989.

LIMA, I.L., FLORSHEIM, S.M.B., LONGUI, E.L. Influência no espaçamento em algumas propriedades físicas da madeira de Tectona grandis Linn. Cerne, Vol. 15, n. 2, p. 244-250, 2009.

LIMA, I.L., LONGUI, E.L., GARCIA, M.F., ZANATTO, A.C.S., FREITAS, M.L.M., FLORSHEIM, S.M.B. Variação radial da densidade básica e dimensões celulares da madeira de Cariniana legalis (Mart.) O. Kuntze em função da procedência. Cerne, Vol. 17, n. 4, p. 517-524, $2011 \mathrm{a}$.

LIMA, I.L., GARCIA, R., LONGUI, E.L., FLORSHEIM, S.M.B. Dimensões anatômicas da madeira de Tectona grandis Linn. em função do espaçamento e da posição radial do tronco. Scientia Forestalis, Vol. 39, n. 89, p. 61-68, 2011b.

LOBATO, C.C.S., DO VALE, I., SOUZA, L.M., ABREU, J.L.L., FERREIRA, G.C., BUFALINO, L. Densidade básica e estabilidade dimensional de madeiras tropicais modificadas por tratamentos térmicos. Nativa: Pesquisas Agrárias e Ambientais, Vol. 8, n. 5, p. 708-714, 2020.

LOPES, J.D.O., GARCIA, R.A., NASCIMENTO, A.M. D., LATORRACA, J.V.D.F. Propriedades físicas da madeira de teca termorretificada. Floresta e Ambiente, Vol. 21, n. 4, p. 569-577, 2014.

MENEZES, W.M., SANTINI, E.J., SOUZA, J.T., GATTO, D.A., HASELEIN, C.R. Modificação térmica nas propriedades físicas da madeira. Ciência Rural, Vol. 44, n. 6, p. 1019-1024, 2014.

MODES, S.K., SANTINI, E.J., VIVIAN, M.A., HASELEIN, C.V. Efeito da termorretificação nas propriedades mecânicas das madeiras de Pinus taeda e Eucalyptus grandis. Revista Ciência Florestal, Vol. 27, n. 1, p. 291-302, 2017.
MUÑIZ, G.I.B., NISGOSKI, S., FRANÇA, R.F., SCHARDOSIN, F.Z. Anatomia comparativa da madeira e carvão de Cedrelinga catenaeformis Ducke e Enterolobium schomburgkii Benth. para fins de identificação. Scientia Forestalis, Vol. 40, n. 94, p. 291-297, 2012

OLIVEIRA, R.I., CHAGAS, P.M., BOUILLET, J.P., LONGUI, E.L., LIMA, I.L., BORDON, B., TOMMASIELLO FILHO, M. Effect of tree spacing on growth and wood density of 38-year-old Cariniana legalis trees in Brazil. Southern Forests: a Journal of Forest Science, Vol. 80, n. 4, p. 311-318, 2018

PANEQUE, L.N., LIMA, I.L., FLORSHEIM, S.M.B., SAKITA, M.N. Temperatura de modificação térmica em algumas propriedades e características da madeira de Eucalyptus. Scientia Agraria Paranaensis, Vol.18, n. 1, p.15-21, 2019.

ROLIM, S.G., PIOTTO, D. Silvicultura e tecnologia de espécies da Mata Atlântica. Belo Horizonte: Editora Rona, 2018.

QUIRINO, W.F., VALE, A.T. Retificação térmica de Eucalyptus grandis. Floresta, Vol. 33, n. 1, p. 60-66, 2002.

SANTOS, H.G., JACOMINE, P.K.T., ANJOS, L.H.C., OLIVEIRA, V.A., LUMBRERAS, J.F., COELHO, M.R., ALMEIDA, J.A., ARAUJO FILHO, J.C., OLIVEIRA, J.B., CUNHA, T.J.F. Sistema brasileiro de classificação de solos. 5. ed. Brasília: Embrapa, 2018. 356 p.

S.A.S. Institute Inc. SAS Procedures Guide. Version 8 (TSMO). SAS Institute Inc. Cary, N.C., 27513, USA, 1999. 